\title{
EFFECTIVENESS OF A MODERN LANDFILL LINER SYSTEM IN CONTROLLING GROUNDWATER QUALITY OF AN OPEN HYDROGEOLOGICAL SYSTEM, SE LITHUANIA
}

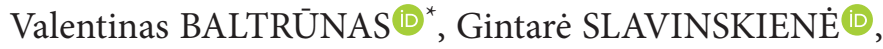 \\ Bronislavas KARMAZA®, Violeta PUKELYTE்
}

Nature Research Centre, Institute of Geology and Geography, Akademijos g. 2, LT-08412 Vilnius, Lithuania

Received 30 March 2020; accepted 03 September 2020

\begin{abstract}
Highlights
> Dissolution of carbonates and dilution were the major processes controlling groundwater quality.

> Modern landfill liner system has no adverse effects on groundwater quality under hydrogeological conditions favourable for the spread of pollutants.

Modern landfill liner systems are not recommended to be constructed in open hydrogeological systems.
\end{abstract}

\begin{abstract}
The work analyzes data of environmental geological mapping, groundwater monitoring of the region municipal waste landfill. This study examines the effectiveness of a modern landfill liner system in minimizing migration of pollutants in the groundwater of an open hydrogeological system. The results showed that dissolution of carbonates and dilution were the major processes controlling groundwater quality. In the landfill's direct impact zone, groundwater was only weakly polluted with biogenic components. Increase in concentrations of these chemical components in this zone was related with the groundwater and surface runoff water flowing from adjacent areas. We can state that the modern landfill liner system we analysed is efficient and has no adverse effects on groundwater quality under hydrogeological conditions favourable for the spread of pollutants. However, in case of an accident, pollutants might pose a great threat on the safety of groundwater. Therefore, even modern landfill liner systems are not recommended to be constructed in open hydrogeological systems.
\end{abstract}

Keywords: landfill, groundwater, geological environment, pollution, Lithuania.

\section{Introduction}

Experience in operating plenty of small landfills shows that it is more rational to use large regional landfills. However, such a policy imposes special requirements on the geological and ecological conditions of the site, landfill design and construction. Advanced spatial planning, taking into account the characteristics of the natural environment, the location of the site, as well as the zoning of industrial, agrarian, recreational, and conservative activities, enables the optimization of landfill site selection.

Landfill site planning and selection in territorial planning documents is a positive practice, especially when using GIS (Pinskuvienè et al., 2004; Bagdanavičiūtė \& Valiūnas, 2012; Ersoy et al., 2012) and the GIS-based Multi-criteria Decision Analysis (MCDA) approach for evaluating the most environmentally suitable landfill sites in the study area (Khan \& Samadder, 2015). In difficult or complicated geological conditions, special environmental geological mapping is used, as is the case in Lithuania (Baltrūnas et al., 2011). The features of natural conditions (sandy soils, high groundwater levels, etc.) determine the design of the landfill and the technologies used, including for bottom mounting and leachate accumulation. Municipal waste landfill leachate formed at different stages of the operation of the landfill has a negative impact on the natural environment (Warith et al., 2004; Baziene et al., 2012). A major problem is the monitoring of operational and post-operational landfill environments, especially groundwater quality. Landfills are one of the most common human activities threatening the natural groundwater quality; therefore, it is relevant to optimize groundwater monitoring systems for landfills

${ }^{*}$ Corresponding author. E-mail: valentinas@baltrunas.lt

Copyright $\odot 2020$ The Author(s). Published by Vilnius Gediminas Technical University

This is an Open Access article distributed under the terms of the Creative Commons Attribution License (http://creativecommons.org/licenses/by/4.0/), which permits unrestricted use, distribution, and reproduction in any medium, provided the original author and source are credited. 
with random leaks under heterogeneous subsurface conditions (Yenigül et al., 2013).

Landfilling is still the most popular waste disposal method in Lithuania. To date, 10 modern landfills constructed in compliance with the European Union requirements operate in the country. However, some authors have noted that the effectiveness of modern landfill liner systems to minimize migration of chemical components is of concern (Edil, 2003). According to Foose (1997), groundwater pollution with some chemical components was detected in the surroundings of modern landfills. Therefore, the aim of this study is to examine the effectiveness of a modern landfill liner system in controlling the groundwater (shallow and intermoraine) quality of open hydrogeological systems: (1) to determine the distribution of hydrochemical zones of different degree of pollution in groundwater along the flow path in open hydrogeological systems and (2) to identify the main hydrochemical and hydrodynamic processes controlling groundwater quality.

\section{Materials and methods}

\subsection{Description of the study site}

The municipal landfill of Kazokiškès, which was selected as a study site, is located in the north-eastern region of Lithuania (54 $\left.48^{\prime} 25^{\prime \prime} \mathrm{N} ; 24^{\circ} 49^{\prime} 15^{\prime \prime} \mathrm{E}\right)$. The landfill was constructed in the place of an exploited sand and gravel quarry in 2008 in compliance with the requirements of the European Union Landfill Directive and is still operating (Figure 1). Landfill bottom is lined with clay and a polymeric membrane, and the leachate formed is collected by drainage systems. Waste storage area is 27 ha. From 1982 to 2007, an unlined landfill was operating in the eastern part of the waste storage area of the landfill. It greatly threatened the safety of groundwater. Later, waste was removed from the territory of the unlined landfill and transported to the landfill we analysed. The leachate formed at the bottom of the unlined landfill was also collected.

The average annual temperature in the area of the landfill studied was approximately $6.0-6.5^{\circ} \mathrm{C}$, the annual

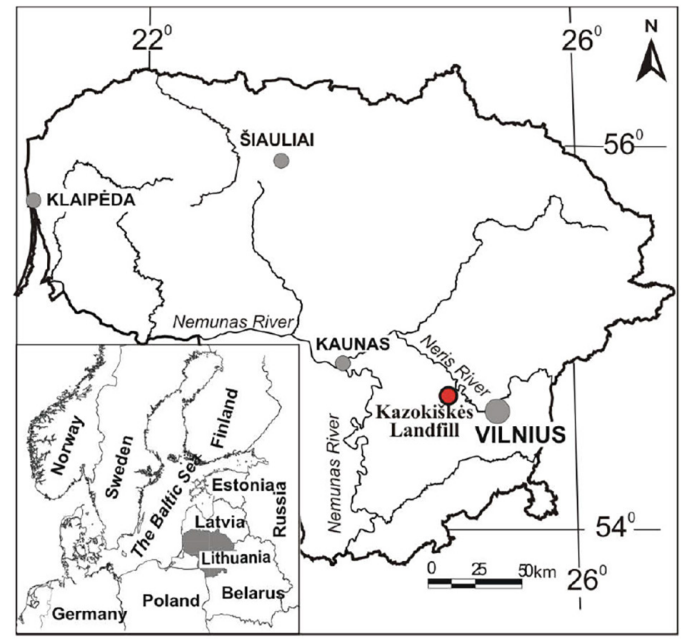

Figure 1. Location of the landfill studied average precipitation was approximately $600-650 \mathrm{~mm}$, and evaporation was approximately $520-540 \mathrm{~mm}$. In general, most precipitation (60-66\%) in Lithuania falls during the warm season (April-October). The nearest villages are farther than $500 \mathrm{~m}$ from the landfill. The nearest groundwater well field is about $1.3 \mathrm{~km}$ west of the landfill.

\subsection{Geological and hydrogeological settings}

The study area is located on the Proterozoic plutonic gabbroid and dioritic granodiorite massifs and the belt of metasomatic rocks that are attributed to the East Lithuanian Domain (Motuza, 2004). This Domain is juxtaposed to the West Lithuanian Domain along the Middle Lithuanian Suture Zone. The crystalline basement rocks are overlain by sedimentary rocks about $600-700 \mathrm{~m}$ thick. The oldest sedimentary rocks were deposited during the Vendian time, while the youngest pre-Quaternary sediments preserved are of the Cretaceous (Turonian) age (Figure 2).

Deposits of the Quaternary age overlay the undulating sub-Quaternary relief, dissected by numerous palaeoincisions (palaeoriver valleys) (Šliaupa et al., 2016). The Quaternary succession was formed during at least five glaciation phases. There is a number of tectonic faults that mark block movements of the crystalline basement. The structures in the Lower Cretaceous and sub-Quaternary surface control the Quaternary succession formation and the hydrographical network (Šliaupa et al., 2016).

The available geological and geomorphological material and created large-scale maps allowed to perform a

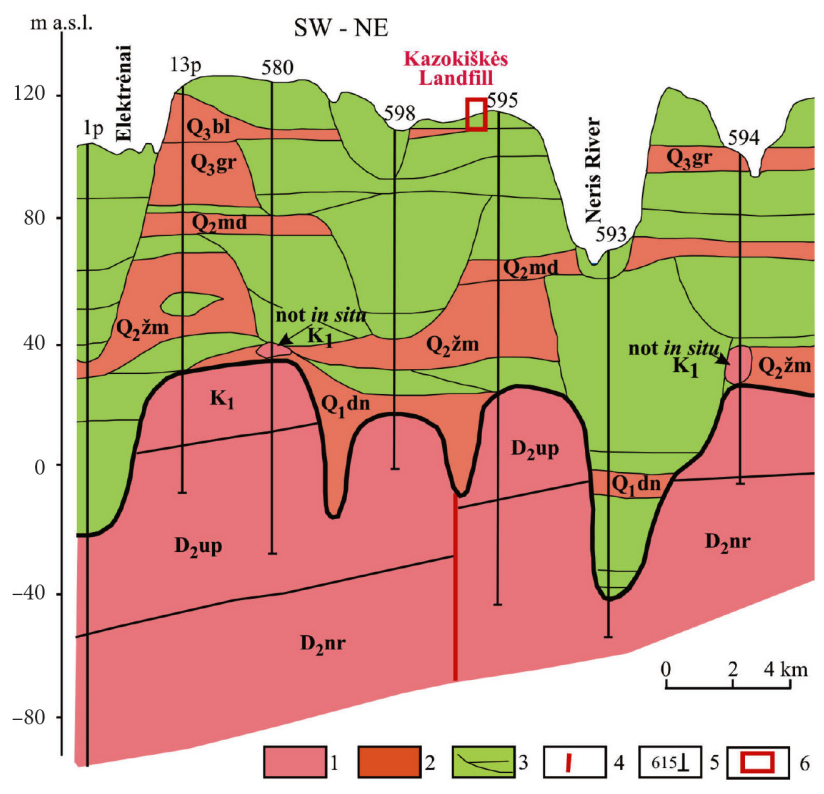

Figure 2. SW - NE geological cross-section across the landfill area studied (place of cross-section see Figure 3; corrected by Šliaupa et al. (2016)): 1 - pre-Quaternary deposits $\left(\mathrm{D}_{2} \mathrm{nr}\right.$ Narva series of Middle Devonian, $\mathrm{D}_{2}$ up - Upninkai series of Middle Devonian, $\mathrm{K}_{1}$ - Lower Cretaceous); 2 - Quaternary glacial deposits - tills $\left(\mathrm{Q}_{1} \mathrm{dn}, \mathrm{Q}_{2} \mathrm{z} \mathrm{m}, \mathrm{Q}_{2} \mathrm{md}, \mathrm{Q}_{3} \mathrm{gr}\right.$, and $\mathrm{Q}_{3} \mathrm{bl}$ Dainava, Žemaitija, Medininkai, Grūda, and Baltija tills); 3 Quaternary non-glacial sediments (gravel, send, silt and other) and boundaries of layers; 4 - tectonic fault; 5 - borehole and its number; 6 - place of Kazokiškès landfill 
lithomorphogenetic (geological-geomorphological) classification by distinguishing seven units (Baltrūnas et al., 2016). Currently, nine fields of mineral resources are dislocated in the study area. Since the Quaternary thickness contains many aquifers, the surface and the whole thickness permeability to fluids and pollutions is of primary importance. The Quaternary thickness is divided into three types, and each type into three sub-types (Baltrūnas et al., 2016). According to the environmental geology mapping data, the predominance of sandy soils (water and pollutant permeable) in the upper part of the Quaternary deposit's strata is typical of the Kazokiškès landfill area (open hydrogeological system) (Figure 3). According to the Master Plan for the territory of Elektrenai municipality, the Kazokiškes environs is located in the forest area (at the border between public and private forests), as well as in the stabilization area of the district geosystem (Elektrenu savivaldybè, 2009).

The Quaternary deposits in the Kazokiškès landfill area are approximately $100 \mathrm{~m}$ thick. Shallow groundwater is found in aqua-glacial sandy deposits. Their thickness in the territory of the landfill varies from 2 to $9 \mathrm{~m}$, and their

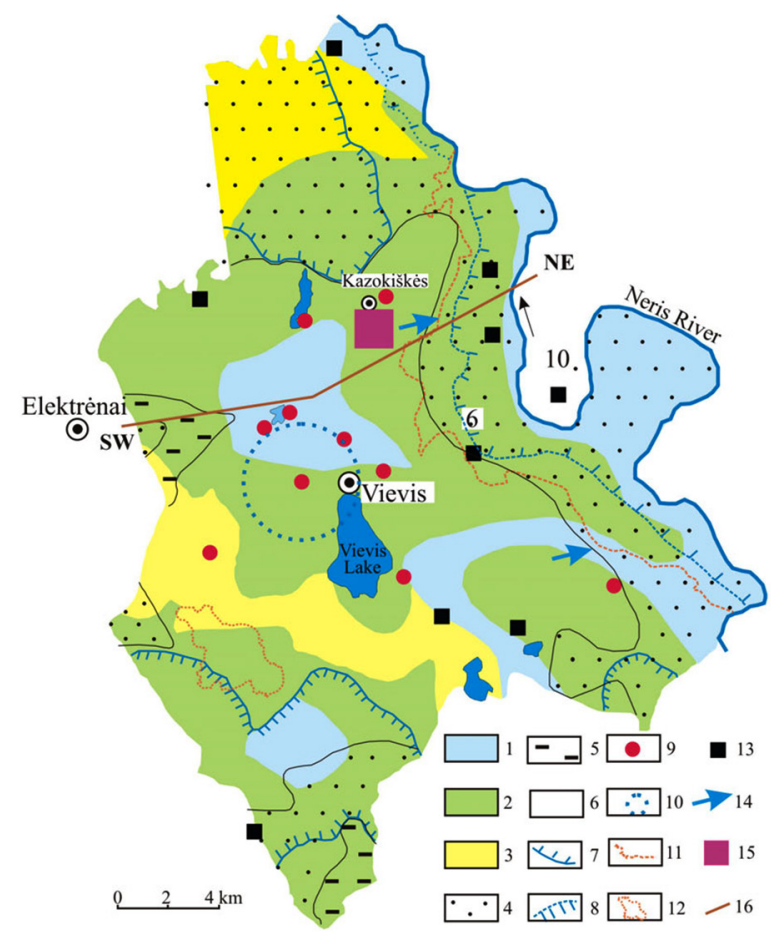

Figure 3. Ecogeological map of Vievis and Kazokiškès area (Vievis eldership) (corrected by Baltrūnas et al. (2016): 1 Aquifers layers (gravel, sand) more than $75 \%$ in Quaternary strata; 2 - aquifers layers (gravel, sand) $50-75 \%$ in Quaternary strata; 3 - impermeable layers (clay, till - morainic loam) 50$75 \%$ in Quaternary strata; 4 - there is no waterproof layer on the surface; 5 - there is solid waterproof layer on the surface; 6 - there is sporadic waterproof layer on the surface (this sign for the rest of the territory); 7 - recharge area for groundwater; 8 - discharge area for groundwater; 9 - water supply system; 10 - Vievis water supply system $3^{\text {rd }}$ chemical pollution control zone; 11 - boundary of Neris Regional Park; 12 - boundary of Pipiriškès Geomorphological Reserve; 13 - mineral deposit; 14 - direction of groundwater flow; 15 - Kazokiškès Landfill; 16 - SW - NE geological cross-section (see Figure 2) hydraulic conductivity is about $8-36 \mathrm{~m} /$ day. Below these deposits lies a lowly permeable moraine glacial deposit (sandy loam, loam) that is approximately $9 \mathrm{~m}$ thick. The hydraulic conductivity of the layer ranges from $2.4 \cdot 10^{-4}$ to $3.4 \cdot 10^{-3} \mathrm{~m} /$ day. Below these layers lies an intermoraine aquifer (sand deposits), which is approximately $5-7 \mathrm{~m}$ thick. The hydraulic conductivity of the layer is about $30 \mathrm{~m} /$ day. In the area of the Kazokiškés landfill and adjacent areas, the natural hydrodynamic regime of shallow groundwater is disturbed. Shallow groundwater flow is directed towards a deep pit formed after excavation. Meanwhile, intermoraine groundwater flow is directed eastward and northeastward towards the area of discharge (Neris River).

\subsection{Data collection and analysis}

The samples of groundwater used in this research were collected from the Kazokiškès landfill in 2008-2015. The monitoring network of the Kazokiškès landfill was composed of six shallow groundwater observation wells and two intermoraine groundwater observation wells (Figure 4 , Table 1).

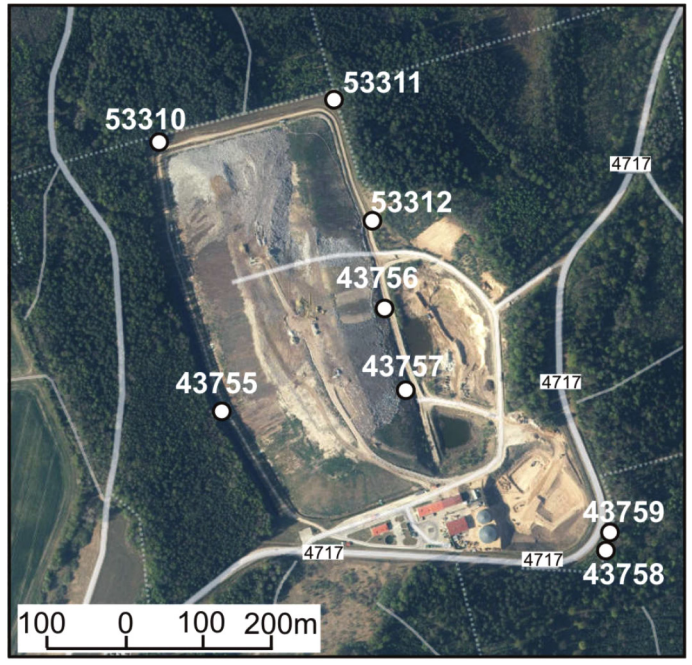

Figure 4. Kazokiškès landfill and location of monitoring boreholes (source: SE “GIS-Centras”, 2020)

Table 1. General characteristics of observation wells of the landfill

\begin{tabular}{|l|c|c|c|c|}
\hline \multirow{4}{*}{ Aquifer } & Well & $\begin{array}{c}\text { Mouth } \\
\text { elevation of } \\
\text { the well (m) }\end{array}$ & $\begin{array}{c}\text { Depth of } \\
\text { the well } \\
(\mathrm{m})\end{array}$ & $\begin{array}{c}\text { Depth of the } \\
\text { interval of the } \\
\text { screen below } \\
\text { surface (m) }\end{array}$ \\
\hline \multirow{4}{*}{ Shallow } & 43756 & 115.00 & 8.60 & $5.48-7.4$ \\
\cline { 2 - 5 } & 43757 & 114.55 & 10.60 & $3.3-5.8$ \\
\cline { 2 - 6 } & 53310 & 132.52 & 29.00 & $22.2-28.5$ \\
\cline { 2 - 6 } & 53311 & 125.70 & 20.40 & $11-15.5$ \\
\cline { 2 - 6 } & 53312 & 117.60 & 14.90 & $11.2-14$ \\
\hline \multirow{4}{*}{$\begin{array}{l}\text { Inter- } \\
\text { mo- } \\
\text { raine }\end{array}$} & 43755 & 122.40 & 22.00 & $13.81-15.6$ \\
\cline { 2 - 6 } & 43759 & 119.51 & 17.50 & $14.52-16.5$ \\
\hline
\end{tabular}


The wells installed in this landfill had diameters of 50$100 \mathrm{~mm}$. Well screens contained gravel filters with a thicknesses of $>20 \mathrm{~mm}$. Well casings and screens were made of chemically inert polyvinyl chloride (PVC). Wellheads were protected from accidental pollution by mechanical, impact-resistant covers. When collecting groundwater samples, all wells were cleaned using special bailers: in this way, three volumes of groundwater that the well could contain were pumped out. Before a bailer was immersed in the next well, it was washed with clean water. Samples were collected in 500-ml plastic bottles prepared in the laboratory and transported to a freezer in the laboratory within $24 \mathrm{~h}$. During the study period, 227 samples were taken from observation wells in the Kazokiškès landfill. The chemical compositions of these groundwater samples were analysed in laboratories licensed by the Lithuanian Environmental Protection Agency using methodologies approved by the Lithuanian Standards Board. The contents of major ions $\left(\mathrm{Na}^{+}, \mathrm{K}^{+}, \mathrm{Ca}^{2+}, \mathrm{Mg}^{2+}, \mathrm{Cl}^{-}, \mathrm{HCO}_{3}^{-}, \mathrm{SO}_{4}^{2-}\right)$, biogenic components $\left(\mathrm{NO}_{2}^{-}, \mathrm{NO}_{3}^{-}, \mathrm{NH}_{4}^{+}\right.$, permanganate oxidation $\left.\left(\mathrm{COD}_{\mathrm{Mn}}\right)\right)$ and heavy metals $(\mathrm{Cu}, \mathrm{Cr}, \mathrm{Zn}, \mathrm{Ni})$ were determined. The potential of hydrogen $(\mathrm{pH})$ of these samples was measured in situ with a calibrated portable instrument. The contents of total dissolved solids (TDS) were determined by calculating the total amounts of anions and cations dissolved in the groundwater. The reliability of groundwater samples was assessed by calculating ion-balance errors, which were generally within $5 \%$.

\subsection{Determination of groundwater quality}

The software XLSTAT (Microsoft Excel @-add-in module) was used for performing multivariate statistical analysis techniques. The hierarchical cluster analysis was used to determine distribution of hydrochemical zones in groundwater along the flow path. The Euclidean metric was used to assess similarities between objects, and Ward's method was applied to assess similarity between clusters. The principal component analysis method was used to identify major factors controlling groundwater hydrochemistry. The GW Chart software was used to create the Piper diagrams and to estimate the hydrochemical facies of groundwater.

The single factor pollution index method was used to assess groundwater quality according to each chemical parameter (Slavinskiene et al., 2019). The single factor pollution index can be determined using the following expression (Huang et al., 2018):

$$
P_{i}=\frac{C_{i}}{S_{i}},
$$

where $P_{i}$ is the pollution index for $\mathrm{i}^{\text {th }}$ chemical parameter; $C_{i}$ is concentration for $i^{\text {th }}$ chemical parameter, $\mathrm{mg} / \mathrm{L}$; and $S_{i}$ is the background value for $i^{\text {th }}$ chemical parameter, $\mathrm{mg} / \mathrm{L}$. The degree of groundwater pollution is classified into five categories according to the single factor pollution index of $i^{\text {th }}$ chemical parameter: $P_{i} \leq 1$ no pollution, $1<P_{i} \leq 5$ light pollution, $5<P_{i} \leq 10$ moderate pollution,
$10<P_{i} \leq 50$ heavy pollution, and $P_{i}>50$ severe pollution (Huang et al., 2018).

\section{Results and discussion}

\subsection{Shallow groundwater quality}

Based on the chemical compositions of shallow groundwater samples taken from observation wells of the Kazokiškès landfill, the observation wells were divided into two clusters (Figure 5).

The identified clusters represent different quality hydrochemical zones in shallow groundwater along the flow path (Table 2). The TDS level of groundwater in Zone I was $<1000 \mathrm{mg} / \mathrm{L}$ and represented freshwater type. The TDS parameter is often used as an index to identify the total groundwater pollution degree (Vashi et al., 2015). Therefore, we can state that the groundwater sample values of the Zone 1 cluster (well No. 3758, 53311, 53312, 53310) can be described as background values. The samples from wells belonging to the Zone II cluster (well No. 43756, 43757) show the quality of groundwater flowing from the landfill. In the groundwater of Zone II, the mean TDS level was $>1000 \mathrm{mg} / \mathrm{l}$. The groundwater of such mineralization is classified as brackish water (Huang et al., 2013). The average TDS level of the groundwater in Zone I was by $60-61 \%$ lower than of the groundwater in Zone II, which means that the groundwater from Zone II was more affected by anthropogenic pollution that groundwater from Zone I.

The mean $\mathrm{pH}$ value of shallow groundwater indicated the neutral nature of this groundwater. The values of major ions, biogenic components and heavy metals of shallow aquifer simples were $627.5 \mathrm{mg} / \mathrm{L}, 9.31 \mathrm{mg} / \mathrm{L}$ and $0.04 \mathrm{mg} / \mathrm{L}$, respectively (Table 2). The concentrations of all chemical components, except for concentrations of $\mathrm{Cl}^{-}, \mathrm{Na}^{+}, \mathrm{HCO}_{3}^{-}$

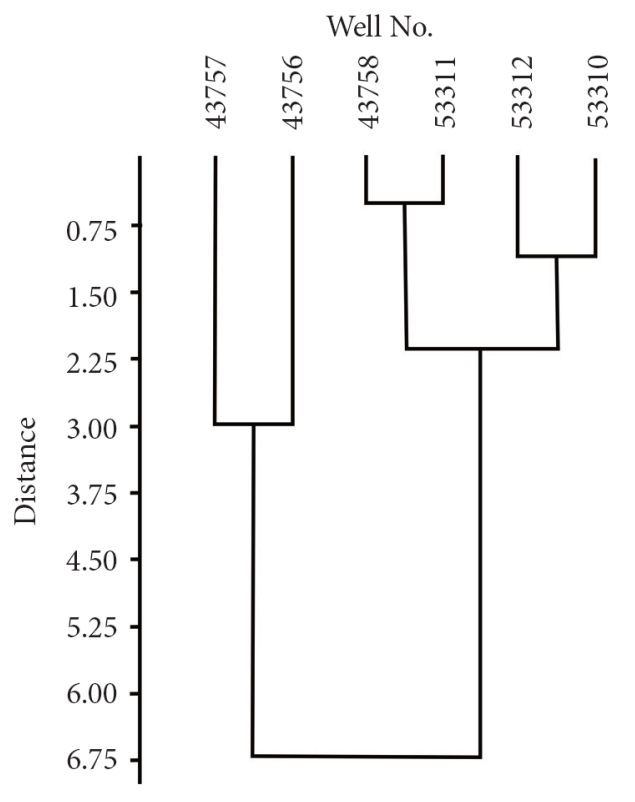

Figure 5. Dendrogram from the Q-mode HCA for the groundwater sampling site 
Table 2. Mean values of physicochemical parameters in shallow groundwater from different hydrochemical zones (clusters) and in intermoraine groundwater in the landfill sites studied

\begin{tabular}{|c|c|c|c|c|c|c|}
\hline \multirow[b]{2}{*}{ Parameter } & \multirow[b]{2}{*}{ Unit } & \multirow{2}{*}{$\begin{array}{c}\text { Lithuania } \\
\text { drinking water } \\
\text { standards (2003) }\end{array}$} & \multicolumn{2}{|c|}{ Shallow aquifer } & \multicolumn{2}{|c|}{ Intermoraine aquifer } \\
\hline & & & $\begin{array}{c}\text { Zone I } \\
\text { (Cluster I) }\end{array}$ & $\begin{array}{c}\text { Zone II } \\
\text { (Cluster II) }\end{array}$ & Well No. 43759 & Well No. 43755 \\
\hline $\mathrm{pH}$ & $\mathrm{pH}$ units & $6.5-9.5$ & 7.44 & 7.26 & 7.43 & 7.57 \\
\hline $\mathrm{EC}$ & $\mathrm{mS} / \mathrm{cm}$ & 2500 & 513.50 & 1352.50 & 715.00 & 573.00 \\
\hline TDS & $\mathrm{mg} / \mathrm{L}$ & & 471.00 & 1165.00 & 660.00 & 504.00 \\
\hline $\mathrm{Cl}^{-}$ & $\mathrm{mg} / \mathrm{L}$ & 250 & 4.65 & 88.79 & 12.70 & 6.98 \\
\hline $\mathrm{SO}_{4}{ }^{2-}$ & $\mathrm{mg} / \mathrm{L}$ & 250 & 19.85 & 66.63 & 63.30 & 45.33 \\
\hline $\mathrm{HCO}_{3}^{-}$ & $\mathrm{mg} / \mathrm{L}$ & & 314.25 & 627.50 & 406.50 & 287.50 \\
\hline $\mathrm{Na}^{+}$ & $\mathrm{mg} / \mathrm{L}$ & 200 & 3.86 & 102.15 & 4.00 & 4.62 \\
\hline $\mathrm{K}^{+}$ & $\mathrm{mg} / \mathrm{L}$ & & 1.10 & 10.33 & 2.20 & 1.12 \\
\hline $\mathrm{Ca}^{2+}$ & $\mathrm{mg} / \mathrm{L}$ & & 94.53 & 160.50 & 123.00 & 96.80 \\
\hline $\mathrm{Mg}^{2+}$ & $\mathrm{mg} / \mathrm{L}$ & & 19.18 & 35.10 & 28.70 & 22.34 \\
\hline $\mathrm{NO}_{3}^{-}$ & $\mathrm{mg} / \mathrm{L}$ & 50 & 2.55 & 0.05 & 0.05 & 24.42 \\
\hline $\mathrm{NH}_{4}^{+}$ & $\mathrm{mg} / \mathrm{L}$ & 0,5 & 0.09 & 1.84 & 0.19 & 0.05 \\
\hline $\mathrm{COD}_{\mathrm{Mn}}$ & $\mathrm{mg} / \mathrm{L} \mathrm{O}_{2}$ & 5 & 3.22 & 9.31 & 2.94 & 1.43 \\
\hline $\mathrm{Cd}^{2+}$ & $\mathrm{mg} / \mathrm{L}$ & 0.01 & 0.0003 & 0.0003 & 0.0003 & 0.0003 \\
\hline $\mathrm{Ni}^{2+}$ & $\mathrm{mg} / \mathrm{L}$ & 0.02 & 0.004 & 0.012 & 0.015 & 0.002 \\
\hline Cr total & $\mathrm{mg} / \mathrm{L}$ & 0.05 & 0.004 & 0.005 & 0.02 & 0.001 \\
\hline $\mathrm{Zn}^{2+}$ & $\mathrm{mg} / \mathrm{L}$ & 3 & 0.040 & 0.040 & 0.10 & 0.04 \\
\hline $\mathrm{Cu}^{2+}$ & $\mathrm{mg} / \mathrm{L}$ & 2 & 0.003 & 0.003 & 0.04 & 0.00 \\
\hline
\end{tabular}

and $\mathrm{Ca}^{2+}$, were similar (within error limits) in the shallow groundwater of both hydrochemical zones. The concentrations of $\mathrm{Cl}^{-}$and $\mathrm{Na}^{+}$in the groundwater of Zone I were by approximately $46 \%$ lower than in the groundwater of Zone II. Meanwhile, the concentrations of $\mathrm{HCO}_{3}^{-}$and $\mathrm{Ca}^{2+}$ in the groundwater of Zone I were by approximately $95 \%$ lower than in the groundwater of Zone II.

The results of standard deviation of chemical components are shown in Figure 6. The mean standard deviation values of biogenic components and heavy metals were approximately equal in shallow groundwater along the flow path (Figure 6). Meanwhile, the mean standard deviation of major ions in the groundwater of Zone II was by approximately $56-98 \%$ higher than in the groundwater of Zone I. It indicates that hydrochemistry in the

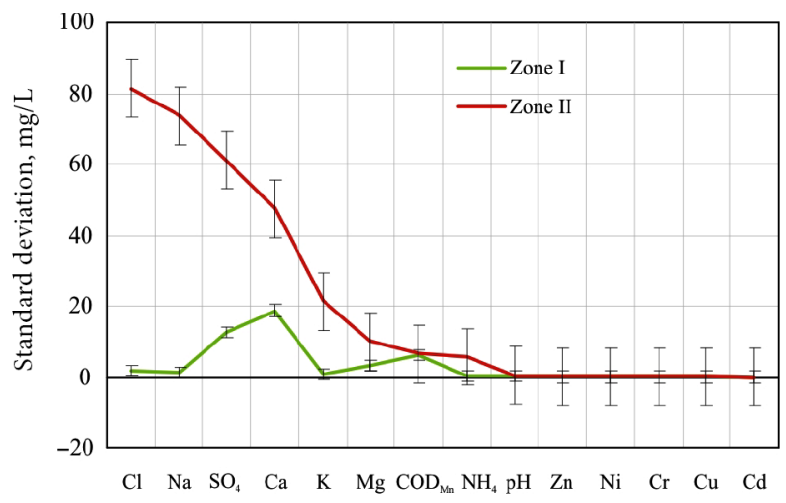

Figure 6. Standard deviation values of chemical components in shallow aquifers of different hydrochemical zones groundwater of Zone I was more stable than that in the groundwater of Zone II.

The Piper trilinear diagram for shallow aquifer constituents is shown in Figure 7. The order of anions and cations was the same in the groundwater of both hydrochemical zones. The general dominance of anions was in the order of $\mathrm{HCO}_{3}>\mathrm{Cl}>\mathrm{SO}_{4}$, while the dominance of cations was $\mathrm{Ca}>\mathrm{Mg}>\mathrm{K}>\mathrm{Na}$. Therefore, both hydrochemical zones of shallow groundwater were characterized by the $\mathrm{HCO}_{3}-\mathrm{Ca}-\mathrm{Mg}$ water type. This water type is characteristic of fresh groundwater.

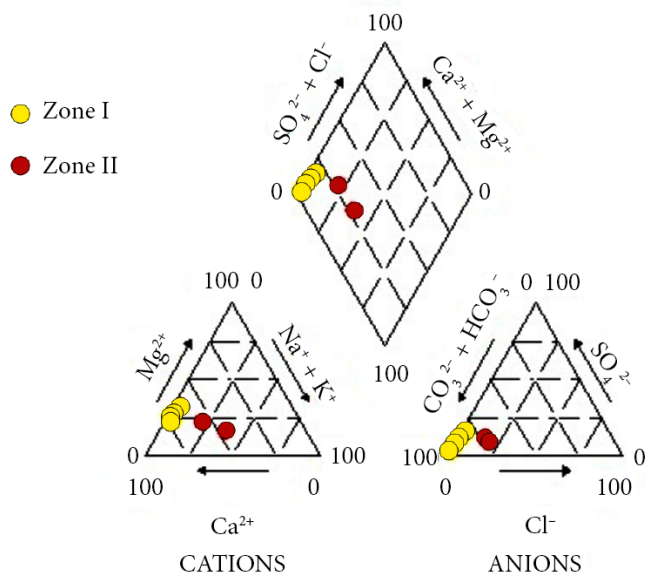

Figure 7. Piper trilinear diagram of shallow groundwater in the landfill sites studied 


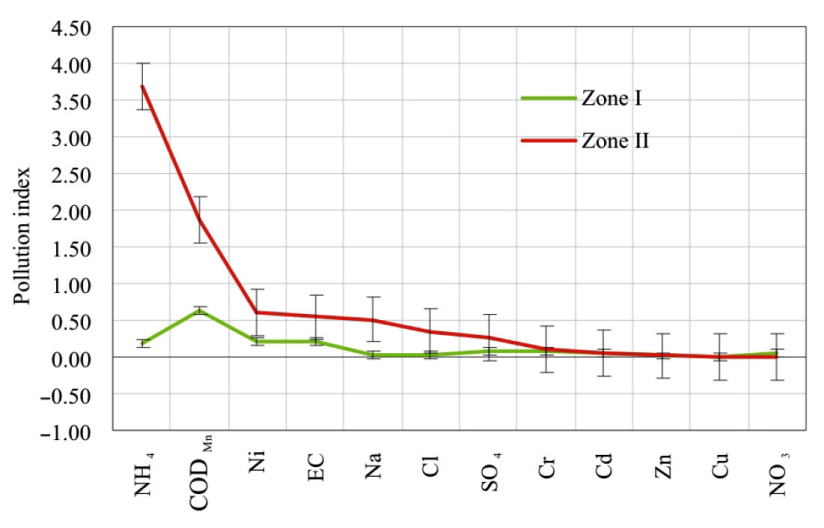

Figure 8. Mean values of single factor pollution index $\left(P_{i}\right)$ in the shallow groundwater of the landfill sites studied

The results of the single factor pollution index $\left(P_{i}\right)$ of major ions and heavy metals in the shallow groundwater of the Kazokiškess landfill showed that groundwater was not polluted by these chemical components, and $P_{i}$ was similar, within error limits, in both hydrochemical zones (Figure 8). Meanwhile, $P_{i}$ of $\mathrm{NH}_{4}^{+}$in the shallow groundwater of Zone I was by $65-95 \%$ lower than that in the groundwater of Zone II. In the groundwater of Zone II, the pollution index of $\mathrm{NH}_{4}^{+}$showed a light degree of ammonium pollution, but the groundwater of Zone I was not polluted with ammonium. According to Christensen et al. (2001), pollution from landfills relates to four groups of pollutants. Therefore, we can state that increase in ammonium concentrations is not the landfill's direct impact on groundwater.

The results of the principal component analysis are summarized in Figures 9-10 and Table 3. Three principal components were obtained with eigenvalues greater

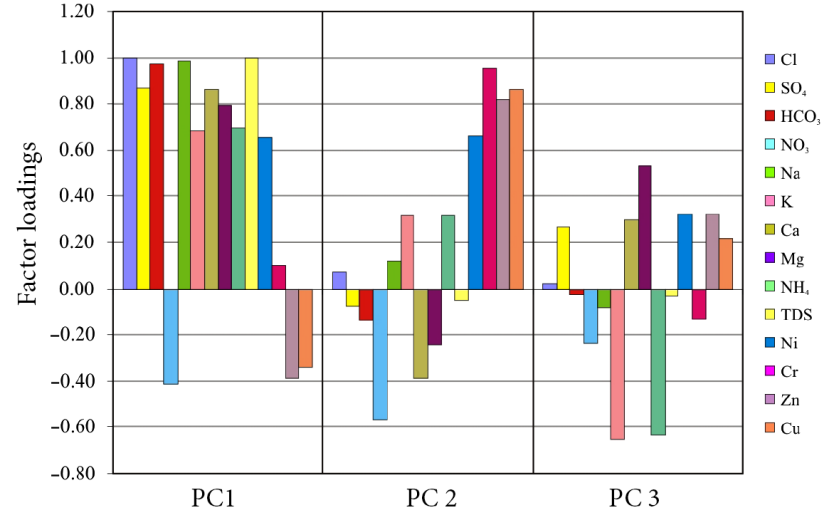

Figure 9. Factor loadings of hydrochemical parameters under three factors

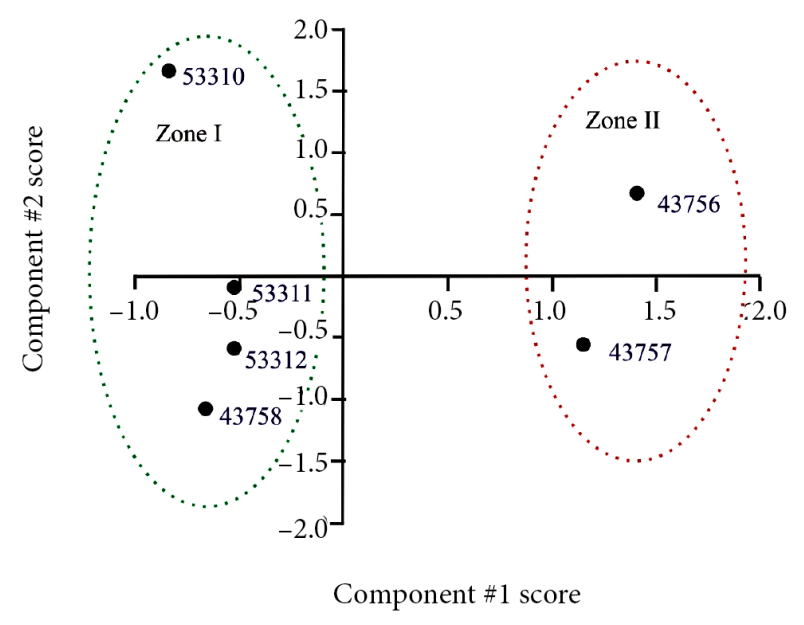

Figure 10. Scatterplots of the two components model eigenvalues

Table 3. Correlation matrix of the principal component analysis

\begin{tabular}{|c|c|c|c|c|c|c|c|c|c|c|c|c|c|c|}
\hline & $\mathrm{Cl}^{-}$ & $\mathrm{SO}_{4}{ }^{2-}$ & $\mathrm{HCO}_{3}^{-}$ & $\mathrm{NO}_{3}^{-}$ & $\mathrm{Na}^{+}$ & $\mathrm{K}^{+}$ & $\mathrm{Ca}^{2+}$ & $\mathrm{Mg}^{2+}$ & $\mathrm{NH}_{4}{ }^{+}$ & TDS & $\mathrm{Ni}^{2+}$ & $\mathrm{Cr}$ & $\mathrm{Zn}^{2+}$ & $\mathrm{Cu}^{2+}$ \\
\hline $\mathrm{Cl}^{-}$ & & 0.88 & 0.96 & -0.43 & 0.99 & 0.69 & 0.84 & 0.79 & 0.71 & 0.99 & 0.70 & 0.15 & -0.30 & -0.26 \\
\hline $\mathrm{SO}_{4}^{2-}$ & 0.88 & & 0.78 & -0.48 & 0.84 & 0.43 & 0.81 & 0.79 & 0.41 & 0.83 & 0.53 & -0.09 & -0.26 & -0.32 \\
\hline $\mathrm{HCO}_{3}{ }^{-}$ & 0.96 & 0.78 & & -0.25 & 0.95 & 0.63 & 0.91 & 0.82 & 0.66 & 0.99 & 0.57 & -0.01 & -0.50 & -0.43 \\
\hline $\mathrm{NO}_{3}{ }^{-}$ & -0.43 & -0.48 & -0.25 & & -0.42 & -0.29 & -0.17 & -0.21 & -0.26 & -0.32 & -0.64 & -0.63 & -0.25 & -0.20 \\
\hline $\mathrm{Na}^{+}$ & 0.99 & 0.84 & 0.95 & -0.42 & & 0.77 & 0.78 & 0.71 & 0.79 & 0.98 & 0.69 & 0.21 & -0.29 & -0.23 \\
\hline $\mathrm{K}^{+}$ & 0.69 & 0.43 & 0.63 & -0.29 & 0.77 & & 0.27 & 0.12 & 0.99 & 0.68 & 0.43 & 0.43 & -0.19 & -0.09 \\
\hline $\mathrm{Ca}^{2+}$ & 0.84 & 0.81 & 0.91 & -0.17 & 0.78 & 0.27 & & 0.95 & 0.29 & 0.88 & 0.42 & -0.31 & -0.57 & -0.56 \\
\hline $\mathrm{Mg}^{2+}$ & 0.79 & 0.79 & 0.82 & -0.21 & 0.71 & 0.12 & 0.95 & & 0.15 & 0.80 & 0.56 & -0.21 & -0.32 & -0.32 \\
\hline $\mathrm{NH}_{4}^{+}$ & 0.71 & 0.41 & 0.66 & -0.26 & 0.79 & 0.99 & 0.29 & 0.15 & & 0.71 & 0.46 & 0.44 & -0.19 & -0.08 \\
\hline TDS & 0.99 & 0.83 & 0.99 & -0.32 & 0.98 & 0.68 & 0.88 & 0.80 & 0.71 & & 0.62 & 0.06 & -0.43 & -0.37 \\
\hline $\mathrm{Ni}^{2+}$ & 0.70 & 0.53 & 0.57 & -0.64 & 0.69 & 0.43 & 0.42 & 0.56 & 0.46 & 0.62 & & 0.67 & 0.39 & 0.44 \\
\hline $\mathrm{Cr}$ & 0.15 & -0.09 & -0.01 & -0.63 & 0.21 & 0.43 & -0.31 & -0.21 & 0.44 & 0.06 & 0.67 & & 0.63 & 0.71 \\
\hline $\mathrm{Zn}^{2+}$ & -0.30 & -0.26 & -0.50 & -0.25 & -0.29 & -0.19 & -0.57 & -0.32 & -0.19 & -0.43 & 0.39 & 0.63 & & 0.98 \\
\hline $\mathrm{Cu}^{2+}$ & -0.26 & -0.32 & -0.43 & -0.20 & -0.23 & -0.09 & -0.56 & -0.32 & -0.08 & -0.37 & 0.44 & 0.71 & 0.98 & \\
\hline
\end{tabular}


than unity, accounting for almost $93 \%$ of total variance in the shallow groundwater dataset. Most of the variance contained in Component \#1 (approximately 56\% of total variance). This component exhibited strong-to-moderate positive association with $\mathrm{Cl}^{-}, \mathrm{HCO}_{3}^{-}, \mathrm{Na}^{+}, \mathrm{Ca}^{2+}, \mathrm{Mg}^{2+}$, TDS, $\mathrm{SO}_{4}^{2-}, \mathrm{K}^{+}, \mathrm{NH}_{4}^{+}$and $\mathrm{Ni}$ (Figure 9). The correlation matrix showed that a strong positive $(>0.75)$ correlation appeared between $\mathrm{Cl}^{-}, \mathrm{Ca}^{2+}, \mathrm{HCO}_{3}^{-}, \mathrm{Mg}^{2+}, \mathrm{SO}_{4}^{2-}$ and TDS (Table 3). Meanwhile, a moderate positive (0.5-0.75) correlation was between $\mathrm{K}^{+}, \mathrm{NH}_{4}^{+}$and $\mathrm{Ni}$. These results indicate that Component \#1 was related with dissolution of carbonate minerals, anthropogenic sources ant redox processes. The highest score (>1.000) underlying Component \#1 concerns all sampling sites of Zone II (Figure 10). Meanwhile, all sampling sites of Zone I were unaffected in this operation because factor \# 1 score ranged from -0.53 to -0.83 .

Component \#2 corresponded to approximately $25 \%$ of total variance. The loadings in the component matrix indicated a strong-to-moderate positive association of $\mathrm{Cr}, \mathrm{Zn}$ and $\mathrm{Cu}$ and a moderate negative association with $\mathrm{NO}_{3}^{-}$ (Figure 9). Sampling site No. 53310 of Zone I exhibited a high score for Component \#2 (Figure 10). A moderate positive correlation between heavy metals indicates anthropogenic source input, meanwhile a moderate negative correlation of $\mathrm{NO}_{3}^{-}$is related with the reduction of nitrate. Hydrodynamic flow was directed from Zone I to Zone II. Therefore, the hydrochemistry of this well was controlled by the groundwater and surface runoff water collected from neighbouring areas.

Component \#3 explained approximately $11 \%$ of total variance. The loadings in the component matrix indicated a moderate negative association of $\mathrm{K}^{+}$and $\mathrm{NH}_{4}^{+}$. The highest score underlying this component concerned sampling site No. 43756 of Zone II. Correlation between $\mathrm{K}^{+}$and $\mathrm{NH}_{4}^{+}$was strong and related with anthropogenic input (Table 3 ). This sampling site was in the deepest place of the quarry; therefore, the hydrochemistry of this well was mostly affected by the groundwater and surface runoff from surrounding areas.

\subsection{Intermoraine groundwater quality}

Analysis of samples from the intermoraine aquifer showed that the TDS level was $<1000 \mathrm{mg} / \mathrm{L}$ in both sampling sites. It means that the intermoraine aquifer was of freshwater type (Table 2). The concentrations of chemical components in both sampling sites were similar (within error limits). The values of major ions, biogenic components and heavy metals in the intermoraine aquifer were $406.5 \mathrm{mg} / \mathrm{L}, 2.44 \mathrm{mg} / \mathrm{L}$ and $0.1 \mathrm{mg} / \mathrm{L}$, respectively. The mean $\mathrm{pH}$ value of intermoraine groundwater of the Kazokiškes landfill indicates the neutral nature of this groundwater (Table 2). Standard deviation values of all chemical component groups were similar in intermoraine groundwater of both sampling sites. Major ions, biogenic components and heavy metals averaged $2.3 \mathrm{mg} / 1,0.3 \mathrm{mg} / \mathrm{l}$ and $0.02 \mathrm{mg} / \mathrm{l}$, respectively. These results indicate that hydrochemistry and infiltration recharge of the intermoraine aquifer of the landfill studied was stabile in the analysed period. Intermoraine groundwater was also of $\mathrm{HCO}_{3}-\mathrm{Ca}-\mathrm{Mg}$ water type. The $P_{i}$ of all chemical components in the intermoraine aquifer was up to 0.75 with an average of 0.24 and 0.13 in the sampling sites No. 43755 (inflow) and No. 43799 (outflow), respectively. It means that the intermoraine aquifer of the studied landfill was not polluted, and the degree of pollution was similar in both sampling sites.

\section{Conclusions and recommendations}

Environmental geology mapping and ecogeological dates from Vievis and Kazokiskes area show that the geological environment is not favorable for landfill: predominance of sandy soils (water and pollutant permeable) in the upper part of the Quaternary deposits strata. The deep and wide valley of the Neris River Valley, 3 to $4 \mathrm{~km}$ to the west, determines the direction of groundwater and pressurized (artesian) water migration.

Two hydrochemical zones of different pollution levels were distinguished along the shallow groundwater flow path in the area of the landfill. The groundwater flowing into the landfill (Zone I) was fresh and not polluted. The concentrations of chemical components were close to the background values. The average TDS level in the shallow groundwater of Zone I was by $60-61 \%$ lower than in the shallow groundwater of Zone II.

The shallow groundwater from Zone II represented the landfill's direct impact on groundwater. The groundwater was of brackish water type. In the shallow groundwater of Zone II, pollution indexes of $\mathrm{NH}_{4}^{+}$and $\mathrm{COD}_{\mathrm{Mn}}$ were the highest among all chemical components, bet the degree of pollution was light. Dissolution of carbonate minerals and dilution were the major hydrogeochemical processes that affected groundwater quality. Of somewhat lower effect on shallow groundwater quality were nitrate reduction processes. The concentrations of biogenic components in the analysed period were stable.

In summary, we can state that increase in chemical component concentrations and higher $P_{i}$ values of organic matter might be related with a more intensive infiltration recharge which prevailed in the second hydrochemical zone. However, increase of said indices was insignificant, and shallow groundwater - due to its good relationship with the atmosphere - held high amounts of oxygen and low amounts of organic matter, and concentrations of chemical components in both hydrochemical zones were actually very close to the background values. Therefore, we can state that the insulation liner of the landfill was reliable, and the landfill had no direct impact on shallow groundwater. Fluctuations in chemical component concentrations can be attributed to hydrodynamic regime disturbances caused by a negative relief form in the area the landfill was constructed. The former quarry accumulated groundwater and surface runoff water from adjacent areas (drainage area reached $0.6 \mathrm{~km}^{2}$ ), and because of 
pollution-favouring hydrogeological conditions such water was polluted with $\mathrm{NH}_{4}^{+}$and $\mathrm{COD}_{\mathrm{Mn}}$ and most likely affected the hydrochemical situation in Zone II. Historical pollution related to the earlier operation of an unilined landfill along with the studied landfill could be another reason for increase in organic matter.

The intermoraine groundwater was of freshwater type and was not polluted. The mean values and standard deviations of major ions, biogenic components and heavy metals were equal within error limits in the inermoraine aquifer along the flow path.

The standard deviations of chemical components in shallow groundwater were by about $80 \%$ greater than in intermoraine groundwater, which demonstrates that shallow groundwater hydrochemistry was strongly controlled by infiltration recharge. Though the landfill had no effect on the hydrogeological environment, in case of an accident pollutants might pose a great threat to the safety of groundwater and intermoraine water. Therefore, construction of landfills in open hydrogeological systems is not recommendable even where hydrodynamic regime does not create suitable conditions for the spread of pollution.

\section{Acknowledgements}

This study was supported by the Lithuanian Ministry of Education, Science and Sport within the programme "Geo-environment and its resources in conditions of climate change and anthropogenic pressure, 2017-2021" (order of the Minister No. V-273, 24-04-2017). The authors are grateful to the Vilnius County Waste Management Center for the results of monitoring being published and made available to the public on the website, to the Geological Survey of Lithuania and to UAB "Grota" for geological and hydrogeological investigations, to Dr. Arūnas Jurevičius, Dr. Rimantė Zinkutė, hydrogeologists Petras Putys and Antanas Marcinonis for fruitful discussions on investigating groundwater of landfills, also to anonymous reviewers for constructive remarks that substantially helped to improve the manuscript.

\section{Conflict of interest}

The authors declare no conflict of interest.

\section{References}

Bagdanavičiūte, I., \& Valiūnas, J. (2012). GIS-based land suitability analysis integrating multi-criteria evaluation for the allocation of potential pollution sources. Environmental Earth Sciences, 68(6), 1797-1812.

https://doi.org/10.1007/s12665-012-1869-7

Baltrūnas, V., Karmaza, B., \& Šliaupa, A. (2016). Vievio apylinkių paviršius, geologiniai ištekliai ir ekogeologinè situacija [Surface, geological resources and ecogeological situation of Vievis area]. Geologijos akiračiai, 3, 13-22 (in Lituanian).

Baltrūnas, V., Valiūnas, J., Šliaupa, A., \& Bagdanavičiūtè, I. (2011). Geologinès aplinkos kartografavimas teritorijų pla- navimui [Environmental geological mapping for territorial planning]. Baltica, 24(Special Issue). Geosciences in Lithuania: Challenges and perspectives, 55-60 (in Lithuanian). https://doi.org/10.13140/RG.2.1.5161.2642

Bazienė, K., Vasarevičius, S., \& Siddiqui, A. A. (2012). Clogging test of landfill leachate drainage using different fillers. Journal of Environmental Engineering and Landscape Management, 20(4), 301-306.

https://doi.org/10.3846/16486897.2012.736865

Christensen, T. H., Kjeldsen, P., Bjerg, P. L., Jensen, D. L., Christensen, J. B., Baun, A., Albrechtsen, H., \& Heron, G. (2001). Biogeochemistry of landfill leachate plumes. Applied Geochemistry, 16, 659-718.

https://doi.org/10.1016/S0883-2927(00)00082-2

Edil, T. (2003). A review of aqueous-phase VOC transport in modern landfill liners. Waste Management, 23(7), 561-571. https://doi.org/10.1016/S0956-053X(03)00101-6

Elektrènų savivaldybè. (2009). Elektrènų savivaldybès teritorijos bendras planas [Master Plan for the territory of the Elektrenai municipality]. https://www.elektrenai.lt/go.php/lit/Elektrenusavivaldybes-teritorijos-bendrasis-planas

Ersoy, H., Bulut, F., \& Berkün, M. (2012). Landfill site requirements on the rock environment: A case study. Engineering Geology, 154, 20-35. https://doi.org/10.1016/j.enggeo.2012.12.005

Foose, G. J. (1997). Leakage rates and chemical transport through composite liners [PhD dissertation]. Department of Civil and Environmental Engineering, University of Wisconsin, Madison.

Huang, G., Liu, C., Sun, J., Zhang, M., Jing, J., \& Li, L. (2018). A regional scale investigation on factors controlling the groundwater chemistry of various aquifers in a rapidly urbanized area: A case study of the Pearl River Delta. Science of the Total Environment, 625, 510-518.

https://doi.org/10.1016/j.scitotenv.2017.12.322

Huang, G., Sun, J., Zhang, Y., Chen, Z., \& Liu, F. (2013). Impact of anthropogenic and natural processes on the evolution of groundwater chemistry in a rapidly urbanized coastal area, South China. Science of the Total Environment, 463-464, 209221. https://doi.org/10.1016/j.scitotenv.2013.05.078

Khan, D., \& Samadder, S. R. (2015). A simplified multi-criteria evaluation model for landfill site ranking and selection based on AHP and GIS. Journal of Environmental Engineering and Landscape Management, 23(4), 267-278. https://doi.org/10.3846/16486897.2015.1056741

Motuza, G. (2004). Viršutinès plutos (kristalinio pamato) sandara ir raida [The structure and the evolution of the upper crust]. In Lietuvos Žemes gelmiu raida ir ištekliai [Evolution of Earth Crust and its resources in Lithuania]. V. Baltrūnas (Ed.). Vilnius, Petro ofsetas, pp. 17-40 (in Lithuanian).

Pinskuvienė, Ž., Valiūnas, J., \& Bagdanavičiūtè, I. (2004). Teritorijos ekogeologinis ịvertinimas tinkamumo sąvartynams įrengti požiūriu naudojant GIS [Ecogeological evaluation of territory for waste disposal using GIS]. Journal of Environmental Engineering and Landscape Management, 12(Suppl 2), 49-53.

SE “GIS-Centras”. (2020). Map of Kazokiškès landfill. http://www.geoportal.lt/map/

Slavinskienė, G., Jurevičius, A., Satkūnas, J., \& Šimanauskienė, R. (2019). Landfill leachate quantity and attenuation distance of inorganic contaminants in the groundwater of different hydrogeological systems: A case study of Lithuania. Baltica, 32(2), 127-138. 
Šliaupa, A., Baltrūnas, V., \& Karmaza, B. (2016). Vievio apylinkių geologinè sandara ir raida [Geological setting and evolution of the Vievis area]. Geologijos akiračiai, 2, 14-23 (in Lithuanian).

Vashi, R. T., Shroff, P., Champaneri, V. A, \& Patel, K. K. (2015) Correlation study among water quality parameters of groundwater of Valsad district of South Gujarat (India). Journal of Fundamental and Applied Sciences, 7, 340-349.

https://doi.org/10.4314/jfas.v7i3.3

Warith, M. A., Evgin, E., \& Benson, P. A. S. (2004). Suitability of shredded tires for use in landfill leachate collection systems. Waste Management, 24, 967-979.

https://doi.org/10.1016/j.wasman.2004.08.004

Yenigül, N. B., Elfeki, A. M. M., van den Akker, C., \& Dekking, F. M. (2013). Optimizing groundwater monitoring systems for landfills with random leaks under heterogeneous subsurface conditions. Hydrogeology Journal, 21, 1761-1772. https://doi.org/10.1007/s10040-013-1013-0 